\title{
FEATURES OF REALIZATION OF INTERNAL OPPORTUNITIES AND PERSONAL POTENTIAL OF PERSONS WITH DISABILITIES IN SOCIALLY SIGNIFICANT ACTIVITY
}

\author{
ОСОБЛИВОСТІ РЕАЛІЗАЦІЇ ВНУТРІШНІХ МОЖЛИВОСТЕЙ \\ ТА ОСОБИСТІСНОГО ПОТЕНЦІАЛУ ОСІБ 3 ІНВАЛІДНІСТЮ \\ У СОЦІАЛЬНО-ЗНАЧУЩІЙ ДІЯЛЬНОСТІ
}

UDC 159.923

DOI https://doi.org/10.32843/2663-

5208.2020.20.45

Overchuk V.A.

Doctor of Economics,

Associate Professor,

Associate Professor at the Department of Psychology

Vasyl' Stus Donetsk National University

Kushnir Yu.V.

Candidate of Pedagogical Sciences, Associate Professor,

Associate Professor at the Department of Psychology

Vasyl' Stus Donetsk National University
The article is devoted to the study of psychological support and socio-psychological adaptation of persons with disabilities, which reflect the level of their interaction and integration with the community and self-determination, the level of realization of internal capabilities of a person with disabilities and his personal potential in socially significant activities, personality, interact with the surrounding society under specific conditions of existence. For Ukraine, the issue of social protection and psychological support of persons with disabilities does not lose its relevance. This is due to a number of reasons, the main of which are psychological, demographic, socio-economic and political. People with disabilities often face specific problems in various spheres of life, which significantly affect their psychological and economic condition. The main groups of barriers that prevent people with disabilities from having a full social life are physical and psychological barriers. The main psychological barriers of people with disabilities are analyzed: communication barrier, business communication barrier, emotional barrier. It was emphasized that the problem of discrimination and stigmatization of persons with disabilities remains acute both in Ukraine and in other countries. The author notes that a formal prohibition of discrimination at the state level does not completely eliminate this problem. This issue is especially painful for those people with disabilities who seek a full working life and professional realization.

It is noted that Ukraine is still at the initial stage of its development in the issues of social and psychological support and life support of people with special needs and is taking the first steps towards approaching international standards. At the same time, modern European integration processes are forcing Ukraine to reconsider existing approaches and existing opportunities to improve the situation of integration / reintegration and the implementation of effective measures aimed at improving the lives of people with disabilities. Key words: persons with disabilities, psychological support, active social life, physical barriers, psychological barriers.

Стаття присвячена дослідженню психоло гічного супроводу й соціально-психологічної адаптації осіб з інвалідністю, які відображають рівень їхньої взаємодії та інтеграції зі спільнотою й самовизначення в ній, рівень реалізації внутрішніх можливостей особи з інвалідністю та їі особистісного потенціалу в соціально-значущій діяльності, у здатноcmi, зберігаючи себе як особистість, взаємодіяти з навколишнім соціумом за конкретних умов існування. Для України питання соціальної захищеності та психологічного супро воду осіб з інвалідністю не втрачає своєі актуальності. Це викликано низкою причин, основними серед яких є психологічні, демограсрічні, соціально-економічні й політичні. Особи з інвалідністю досить часто стикаються зі специфрічними проблемами в різних сфрерах життя, які суттєво впливають на їх психологічний, економічний стан. Виділено основні групи бар'єрів, які перешкоджають особам з інвалідністю мати повноцінне соціальне життя, а саме фрізичні та психологічні бар'єри. Проаналізовано основні психологічні бар'єри людей з інвалідністю, такі як комунікативний бар'єр, бар'єр ділового спілкування, емоційний бар'єр. Наголошено на тому, що проблема дискримінації та стигматизаціі осіб з інвалідністю залишається гострою як в Україні, так і в інших країнах світу. Авторка зазначає, що фрормальна заборона дискримінації на державному рівні не усуває цю проблему повністю. Особливо болючим че питання є для тих осіб з інвалідністю, які прагнуть повноцінного трудового життя й професійної реалізації.

Зазначено, що Україна в питаннях сочіально-психологічного супроводу та життєзабезпечення осіб з особливими потребами досі перебуває на початковому етапі свого розвитку й робить перші кроки з наближення до міжнародних стандартів. Водночас сучасні процеси євроінтеграції змушують Україну переглянути чинні підходи та наявні можливості покращення ситуації інтеграції реінтеграції та вжиття ефективних заходів, спрямованих на покращення життя осіб з інвалідністю.

Ключові слова: особи з інвалідністю, психологічний супровід, активне соціальне життя, фрізичні бар'єри, психологічні бар'єри.
The question of integration of persons with disabilities into public life has existed throughout human existence. At the same time, despite the urgency of the issue, it will not be a secret that the level of solving this problem remains low even in developed countries. An active social life, which includes work, leisure, communication with family and friends, is so ordinary for many people that not everyone even realizes the value of what they have. At the same time, there are people among us for whom each of these elements of everyday life is extremely important because they are entirely or partially deprived of such seemingly ordinary activities. We are talking about people with disabilities who cannot always find their place in our society because they often have limited access to education, the labour market, communication with other people and a decent holiday. 
At the moment, almost 3 million people with disabilities live in Ukraine, or $6.3 \%$ of the total population, of which more than $80 \%$ are of working age. Today, in these difficult conditions, that research of psychological support of personality and socio-psychological adaptation of the character, which reflects the level of its interaction and integration with the community and self-determination in it. The level of realization of inner capabilities and personal potential in socially significant activity, in the ability, while maintaining himself as a person, to interact with the surrounding society under specific conditions of existence.

The problem of rehabilitation and employment of people with disabilities remains relevant today for many countries around the world. Despite some progressive steps that have been taken and are being taken to improve the situation, the percentage of people with disabilities who have limited access to education, limited opportunities for social activity, and difficulties in finding employment and professional realization, in general, remains relatively high. Quite often, the cause of such problems is called lack of financial resources. At the same time, funding is only one element of an integrated institutional environment in which other factors play an equally important and sometimes decisive role in the process of rehabilitation and integration of persons with disabilities.

Today, society is overly concerned about the problem of disability, which has a tendency to increase and is the result of injury, contusion or mutilation due to hostilities in the east, deteriorating environmental conditions in Ukraine, malnutrition of a large part of the population, increased injuries and more.

At the moment, in these difficult conditions, that research of psychological support of personality and socio-psychological adaptation of nature, which reflects the level of its interaction and integration with the community and self-determination in it, the level of realization of inner capabilities and personal potential in socially significant activity, in the ability, while maintaining himself as a person, to interact with the surrounding society under specific conditions of existence. This problem is considered by the majority of authors (B.N. Almazov, S.A. Belicheva, T.M. Dychev, M. Ratter, etc.), as the process of disturbance of the homeostatic balance of the person and the environment, as disturbance of adaptation of the individual owing to the action of these or those reasons; as a violation caused by the inconsistency of the innate needs of the individual to the requirements of the social environment; as the inability of the individual to adapt to their own needs and demands.

Socio-psychological adaptation changes the inner world of man: there are new intentions, knowledge of the activities in which he is engaged, there are a self-correction and self-determination of the individual, changes in self-esteem, goals and objectives of the individual, and others. Based on these grounds, there is a change in attitude to self-affirmation; the individual acquires the necessary knowledge, skills and abilities. All this determines the essence of its socio-psychological adaptation to society, the success of its course.

It is worth noting that the socio-psychological adaptation of people with disabilities is associated with the optimization of the socio-psychological existence of the individual, adjusted to its capabilities, needs and values. But for a long time, society was dominated by the idea that the limitation of a person's functional capabilities should automatically lead to a reduction in his needs. And most importantly, concerning people with disabilities, it was usually about basic needs, not about the values that determine the meaning of their lives and, above all, spiritual matters. People with disabilities were identified with basic needs, not with costs, the difference between which is that the former push a person behind, and the latter - attracts to the front.

The development of a person with a disability, his self-awareness under the influence of various social factors leads to the fact that there may or may not be the resolution of contradictions, which ultimately leads to the adaptation or maladaptation of the individual. If new for the individual social values, types of behavior contradict previously learned, which are part of his inner world, the balance between external and internal is disturbed, there is a psychological dissonance. It leads, in our opinion, to the formation of negative mental qualities and characteristics of a person with a disability.

In the process of internalization of social influence, a person with a disability changes his old concepts, social norms, transforms them, i.e. there is an internal reorganization of the psychological structure, the inner world of the individual, which is usually accompanied by profound emotional experiences.

An analysis of the psychological characteristics of people with disabilities revealed another fact, namely, due to their unnecessary need in the labour market and their social isolation is the process of their removal from society. This world inhibits the formation of their active life position. Most of these people do not form a strong sense of trust in the world, in other people. As a result, people with disabilities often perceive everyone as a hostile environment. Most of them do not live a full life, they do not have sufficient motivation to communicate, and therefore the result is their isolation, alienation from people. Under these conditions, the formation of "diffuse" identity and their long delay in the egocentric position is possible.

New research indicates that even with the improvements made, most people with disabilities remain a socially vulnerable group, do 
not have a full social life, have difficulty finding employment or cannot go beyond specialized enterprises, and are subject to discrimination and stigmatization by society [1]. However, this problem and its causes in practice are much more complex and are not limited to physical obstacles. Several other factors complicate it even more.

For Ukraine, the issue of social protection and psychological support for people with disabilities is significant. It is due to several reasons, the main of which are psychological, demographic, socio-economic and political [2].

Firstly, therearenegativetrends in the reproduction of human capital, the expansion of its degradation zone, which threatens the socio-economic security of the state primarily due to an increase in the number of people with disabilities, especially working age, with acute depopulation.

The main reasons for the increase in the number of people with disabilities, especially children, are the impoverishment of a large part of the population, which has significantly affected its health, as well as the unsatisfactory state of the environment, primarily caused by the devastating consequences of the Chornobyl disaster, at work and home, the growth of crime.

Secondly, the growth of poverty, especially among the socially vulnerable, including people with disabilities, has prompted them to change their psychological behavior, often from observational, expectant and passive, to forced hard work to earn a living, family. That is, the distribution of roles within the family has begun to change. People with special needs are moving from the category of dependents to breadwinners.

Thirdly, people with disabilities belong to socially vulnerable groups who cannot compete in the labour market on an equal footing with others due to their physical or mental disabilities, especially since the labour market situation is currently unfavorable.

Fourthly, in the current socio-economic conditions, restructuring of the employment system, vocational training, social protection, etc., there is an urgent need to assist in the socio-psychological adaptation of citizens to new economic and political conditions, as well as their rehabilitation. Of course, this primarily applies to people with disabilities.

The experience of psychologists shows that people with special needs often face specific problems in various spheres of life, including education, employment, social activities, family relations, life and leisure, communication and more.

Persons with disabilities belong to different groups according to the level of complexity of their physical or psychophysical condition, place of residence, social status. The severe chronic somatic disease significantly changes first of all the whole socio-psychological situation of human development. It significantly affects the level of her mental capabilities in the implementation of activities, leads to a limited range of contacts with others, often for objective or subjective reasons leads to a limitation of its activities as a whole, i.e. changes the accurate place man in life, and, as a consequence, his inner position to all the circumstances of life [3].

Defects of people with disabilities significantly complicate their contacts with the environment, limit their participation in public life, and negatively affect personal development: they cause feelings of anxiety, insecurity, and lead to the formation of inferiority, selfish and antisocial attitudes.

The two main groups of barriers that prevent people with disabilities from having a full social life, including professional realization, are physical and psychological barriers. The focus is usually on the first group, which is directly related to the physical limitations of a person with a disability. At the same time, psychological barriers are equally important. People with disabilities and everyone else can be the source of these barriers.

Firstly, the person with a disability may seeka life more isolated from society. Such people are often closed off in their world. They have a very narrow circle of friends, which includes family members, doctors, possibly several friends and the same people with disabilities. The first reason for this way of life may be the restriction of physical activity and the simultaneous lack of appropriate infrastructure, which makes a person a kind of prisoner of his own home. Also, a person may despair of him and others and refuse the opportunity to realize themselves in society.

Secondly, other people's reluctance to accept people with disabilities into their environment remains common. The main psychological barriers for people with disabilities are these.

1) Communication barrier is a communication disorder, one of the most challenging social problems of children and youth with disabilities, which is a consequence of emotional protective self-isolation. The communication barrier creates motivational, ethical, emotional difficulties [4]. Motivational difficulties: excessive motivation (for example, "worried and did not say everything, remembered"); lack of reason (I do not want to understand, not interesting), etc. Ethical (moral) difficulties: lack of tact, tolerance; audacity, audacity; gossip, rumors, deception, meanness, dishonesty; envy, bias, etc. Emotional challenges: untidy, outrageous appearance; bold postures, gestures, manners, habits, etc.; brutal tone, tone of voice, etc.

2) The barrier of business communication creates problems associated with the characteristics of healthy people and people with functional limitations of health, which arise when paying attention to those aspects of personality that he is not aware of or wants to hide, in our case - this physical defects. Some authors, when considering the problem of social integration of people 
with poor physical health, even suggest introducing the concept of "ideological equality" to denote the perception of a person with disabilities as equal and having a different worldview, different lifestyle and particular needs [3].

3) The emotional barrier consists of people's emotional reactions and is two-way. That is, on the one hand, healthy people may show curiosity, ridicule, inconvenience, guilt, hyperopia, fear. On the other hand, people with special needs can wait for self-pity, hyperopia, can blame someone for their defect, seek isolation, etc. [4].

A person with a disability may have a negative experience of communicating with so-called "normal" people due to discrimination, contempt, misunderstanding, insults [5]. The problem of racism and stigmatization of people with disabilities remains acute both in Ukraine and in other countries [1]. At the same time, it is evident that the formal prohibition of discrimination at the state level does not eliminate this problem. This issue is incredibly painful for those people with disabilities who seek a full working life and professional realization. Discrimination can take various forms when hiring or refusing a job, offering an appointment with a lower qualification level, offering worse pay conditions. Also, in the course of work, discrimination against a person with a disability can be manifested in the daily treatment of this person, blocking career opportunities without objective reasons, ignoring the success of this person and his contribution to joint activities.

Another group of barriers is educational information. Thus, not in every area, people with disabilities have the opportunity to receive full counselling on services and organizations that can help them, as well as on opportunities in the labour market. As for education, many educational institutions in Ukraine are still not adapted to the fact that their students may include people with disabilities.

The combination of barriers discussed above can lead to another problem. Some groups of people with disabilities work in specialized enterprises, for example, in UTOS enterprises. But they do not have access to the open labour market. For some people with disabilities, enter- ing the free labour market is very difficult due to physical reasons. In contrast, other people with disabilities have fewer restrictions and can compete with regular candidates for jobs in nonspecialized enterprises. However, they are hindered by psychological barriers or lack of education or information.

Ukraine is still at the initial stage of its development in the issues of social and psychological support and life support of people with special needs. It is taking the first steps toward approaching international standards [2]. Therefore, there is still a wide range of urgent problems, and there is no appropriate mechanism to solve them.

At the same time, modern European integration processes are forcing Ukraine to reconsider existing approaches and existing opportunities to improve the situation of integration/reintegration andtheimplementationofeffectivemeasuresaimed at improving the lives of people with disabilities.

\section{LITERATURE:}

1. The disability employment puzzles: a field experiment on employer hiring behavior / M. Ameri, L. Schur, M. Adya, S. Bentley, P. McKay, D. Kruse. Labor and Employment Relations Association conference. 2015. P. 1-70.

2. Про реабілітацію осіб з інвалідністю в Україні : Закон України від 6 жовтня 2005 року № 2961-IV. База даних «Законодавство України» / ВР України. URL: http://zakon.rada.gov.ua/laws/show/2961-15 (дата звернення: 15.10.2018).

3. Дікова-Фаворська О.М. Адаптаційні можливості освіти осіб з інвалідністю. Соціальні технології : актуальні проблеми теорії та практики : міжвузівський збірник наукових праць. 2009. № 42. URL: http://www.nbuv.gov.ua/portal/Soc_Gum/Staptp/2009_ 42/files/42_07Dikova 202Favorska.pdf.

4. Завірюха Л.А. Оволодіння особистістю засадами толерантності у студентському середовищі. Актуальні проблеми навчання та виховання людей з особливими потребами : збірник наукових праць. Київ : університет «Україна», 2004. 448 с.

5. Алпатова П.С., Зуб Т.С. Людина з обмеженими фрізичними можливостями в міському середовищі. Український соціум. 2006. № 1. С. 7-16. 